UDC $614.876+614.878$

DOI: $10.21668 /$ health.risk/2021.1.04.eng

Research article

\title{
HEALTH RISK ANALYSIS AS PER RADIATION AND CHEMICAL FACTORS IN A ZONE INFLUENCED BY A NUCLEAR LEGACY OBJECT
}

\section{S.M. Kiselev, N.K. Shandala, T.N. Lashchenova, Yu.N. Zozul, V.V. Shlygin, T.I. Gimadova, A.N. Malakhova}

State Research Center Burnasyan Federal Medical Biophysical center of Federal Medical Biological Agency, 46 Zhivopisnaya Str., Moscow, 123182, Russian Federation

Rehabilitation programs for nuclear legacy objects in north-western regions in Russia involve decommissioning; a former coast technical support base belonging to the RF Navy and located on the Gremikha peninsula in Murmansk region is now being removed from service. At present spent nuclear fuel is being extracted from ship reactors with liquidmetal coolant and nuclear wastes that have been accumulated during active operations are being treated. The current activities at the site result in complex influence on the environment determined by both radiation and non-radiation contaminants.

The present work focuses on examining a hygienic situation existing in residential areas located close to this nuclear legacy object. In general, radiation situation in residential areas is determined by technogenic contaminants, basically ${ }^{137}$ Cs and ${ }^{90} \mathrm{Sr}$ radionuclides.

Our research has revealed that at the moment their contents in the environmental objects correspond to background levels that are typical for the examined region. Chemical contamination detected in residential areas is characterized with elevated heavy metals contents ( $\mathrm{Cd}, \mathrm{As}, \mathrm{Pb}, \mathrm{V}, \mathrm{Zn}, \mathrm{Cu}$ etc.) in soils in urban settlements that are higher than background levels. We detected lead and zinc concentrations that were higher than MPC. Total soil contamination with heavy metals $(\mathrm{Zc})$ is still «permissible» in most residential areas. Carcinogenic health risk for people living in the examined residential areas does not exceed $10^{-6}$ as per radiation and chemical factors.

Research results allow assessing the current hygienic situation as normal and concluding that decommissioning of SZC «SevRAO» objects (Gremikha section) does not exert negative impacts on the environment and health of people living in residential areas located nearby. The obtained data give grounds for controlling activities when environmental monitoring is accomplished during works aimed at recovering contaminated areas where nuclear legacy objects are located.

Key words: radiation-hazardous objects, nuclear legacy, SZC «SevRAO», Gremikha, carcinogenic risk, technogenic radionuclides, heavy metals, hygienic assessment, population health.

(C) Kiselev S.M., Shandala N.K., Lashchenova T.N., Zozul Yu.N., Shlygin V.V., Gimadova T.I., Malakhova A.N., 2021

Sergey M. Kiselev - Candidate of Biological Sciences, Head of the Laboratory for Regulating Surveillance over Nuclear Legacy Objects (e-mail: sergbio@gmail.com; tel.: +7 (985) 761-10-17; ORCID: https://orcid.org/0000-0002-2613-2293).

Nataliya K. Shandala - Doctor of Medical Sciences, Deputy to Managing Director (e-mail: shandala-fmbc@bk.ru; tel.: +7 (499) 190-93-29; ORCID: https://orcid.org/0000-0003-1290-3082).

Tatiana N. Lashchenova - Doctor of Biological Sciences, v (e-mail: tlaschenova@yandex.ru; tel.: +7 (910) 404-91-10; ORCID: https://orcid.org/0000-0002-6682-1261).

Yuliya N. Zozul - Candidate of Biological Sciences, Researcher (e-mail: julnik@list.ru; tel.: +7 (985) 920-39-83; ORCID: https://orcid.org/0000-0003-3154-1806).

Vladimir V. Shlygin - Junior Researcher (e-mail: vladvas83@mail.ru; tel.: +7 (499) 190-94-18; ORCID: https:// orcid.org/0000-0002-1190-9557).

Tamara I. Gimadova - Senior researcher (e-mail: tamara.gimadova@icloud.com; tel.: +7 (499) 190-96-65; ORCID: https://orcid.org/0000-0001-9144-2610).

Anna N. Malakhova - Engineer (e-mail: lawbro@yandex.ru; tel.: +7 (499) 190-96-65; ORCID: https://orcid.org/00000003-3868-3671). 
According to the Basic Principles of State Policy of the Russian Federation in the Field of Nuclear and Radiation Safety approved by the RF President in $2018^{1}$ a set of activities is now being implemented that are aimed at remediating nuclear legacy sites and facilities. These include civilian and military facilities created before the current nuclear and radiation safety requirements had been approved. Among them, some facilities are at the stage of decommissioning, disposal and burial.

The assessment of the potential anthropogenic impact exerted by nuclear and radiation hazardous facilities on the population and the environment is a socially significant factor and a subject for studying within various research projects, including international ones ${ }^{2}[1-5]$.

The comparative analysis of the potential hazard caused by radiation sources and impact assessment for the population and the environment is based on a risk approach. It is an advanced tool for environmental and public health management [6-9]. The current risk assessment methodology is based on studying and analyzing all the factors affecting the environment and indirectly humans. Risk assessment is also carried out for independent and combined impacts on population and ecosystems. The assessment result provides the basis for subsequent comparative analysis and risk management that significantly optimize the nuclear legacy sites decommissioning and the remediation of their territories [10-14].

This paper presents the health physics assessment of the environment. It also presents a study of the potential impact on the local population by decommissioning the Navy's former shore technical base (hereinafter referred to as STB) located in the northwest of the country (Murmansk region). In 1958, STB was built on the Gremikha peninsula. It was used for the stationing of nuclear submarines, recharging of reactors with water and liquidmetal coolants, carrying out dock inspections and repairs. Since the base was in active operations, substantial quantities of spent nuclear fuel (SNF) and radioactive waste (RW) were being accumulated on its territory. Their total activity is $13 \cdot 10^{15} \mathrm{~Bq}$ [15]. In the late $1980 \mathrm{~s}$ it fell out of use after relocating the nuclear submarines division and removing military personnel from the base. It resulted in the degradation of the base infrastructure and the destruction of engineering barriers around SNF and RW storage facilities, and artificial radionuclides migration into the environment. The facility was taken over by Rosatom Corporation for decommissioning and remediation of contaminated territories. It is necessary to provide safety for the local population and prevent further environmental contamination. The Gremikha division of the North-western Center for Radioactive Wastes Management «SevRAO» (hereinafter NWC «SevRAO» Gremikha) was created at the territories of the former STB. This facility belongs to the Federal State Enterprise for RW management «RosRAO» (it has been called «The Federal Ecologic Operator» since 2020). At present, the main facility operations deal with RW and SNF management during disassembling of spent removable parts of nuclear submarines reactors with liquid-metal coolant and treating of high-level RW stored on an open ground. After removing SNF and RW, it is planned to remediate the contaminated territories according to the «brownfield» scenario. Due to operational specificity, the object belongs to the $1^{\text {st }}$ radiation hazard category. According to it, the site is divided into three zones, namely, an operational zone with controlled access, a health protection zone, and a supervision area. Operators monitor the radiation situation in all three zones following established requirements.

Previous activities at the site and ongoing decommissioning measures dictate the necessity to consider the potential contamina-

\footnotetext{
${ }^{1}$ On approval of the Basics Principles of State Policy in the Field of Nuclear and Radiation safety in the Russian federation for a period up to 2025 and further on: the RF President Order issued on October 13, 2018 No. 585. The RF President. Available at: http://www.kremlin.ru/acts/bank/43631 (10.07.2020) (in Russian).

${ }^{2}$ Assessing the Long Term Safety of Radioactive Waste Management. Regulatory Guide G-320. Ottawa, Ontario, Canadian Nuclear Safety Commission December Publ., 2006, 41 p.
} 
tion of the site and surrounding areas with radioactive and non-radiological contaminants $[16,17]$. Non-radiological contaminants include a wide range of organic and inorganic ones such as heavy metals that can be found in emissions from gas-cutting machinery, welding, painting, and deactivating works performed during implementation of the current remediation activities. Therefore, the main goal of the research was to perform a complex health risk assessment of public exposure to radiation and chemical environmental contaminants living in the vicinity of NWC «SevRAO» Gremikha during decommissioning the nuclear legacy site.

Materials and methods. Measurements, sampling, and sample analysis were performed following the conventional procedures approved by the certified Laboratory Centre at Burnasyan Federal Medical Biophysical Center (Certificate No. RA.RU.21БУ01).

The data were subjected to statistical analysis using generally accepted methods (GOST R ISO 16269-7-2004) ${ }^{3}$. Microsoft Excel was used for calculations. Gamma dose rates were measured using a portable Na-I scintillation detector (MCS-01A «Multirad-M» (NTTs Amplituda, Russia)). Gamma-spectrometric («CANBERRA» gamma-spectrometer with semi-conductor germanium detector, the USA) and radiochemical methods were used to determine artificial radionuclides in environmental media.

Public dose assessment was performed according to the recommendations by the International Commission on Radiological
Protection (ICRP) and the International Atomic Energy Agency (IAEA), taking into account regional background levels ${ }^{4}$ [18]. The average annual effective dose (hereinafter called AAED) was calculated according to the national radiation safety standards $(\mathrm{NRB}-99 / 2009)^{5}$.

AAED of external exposure (both indoors and outdoors) was conservatively assessed by TLD (thermoluminescent dosimetry (TL-dosimeters with lithium-fluoride-based detectors (DTG-4), $1 \mathrm{~g} / \mathrm{cm}^{2}$ ).

Internal exposuredoses due to ingestion pathway were calculated according to Guidelines MR 2.6.1.0063-12 ${ }^{6}$ :

$$
E_{i, k}^{\mathrm{int}}=\sum_{k} \sum_{j}\left(e_{i}^{k} \cdot V_{i, j} \cdot S_{k, j}\right),
$$

$e^{k}, \mathrm{mSv} / \mathrm{Bq}$ is an age- dependent dose coefficient for the $\mathrm{k}$-th radionuclide (ingestion pathway), NRB-99/2009;

$V_{i, j}, \mathrm{~kg} /$ year, is annual consumption of the $\mathrm{j}$-th product (consumed drinking water is $730 \mathrm{~L})$

$S_{k, j}, \mathrm{~Bq} / \mathrm{kg}$, is average annual specific activity of the k-th radionuclide in the $\mathrm{j}$-th food product.

Metals were determined with atomic-absorption spectroscopy («Kvant 2 AT», Russia).

Chemical contamination of soil was evaluated via comparison with $\mathrm{MPC}^{7} / \mathrm{TPC}^{8}$, concentration factor $\left(\mathrm{K}_{\mathrm{c}}\right)$ and cumulative pollution index $\left(\mathrm{Z}_{\mathrm{c}}\right)$ according to the Guidelines MU 2.1.7.730-99 ${ }^{9}$. Concentration factor $K_{c}$ is determined as a ratio between metal concentra-

\footnotetext{
${ }^{3}$ GOST R ISO 16269-7-2004. Statistical procedures. Statistical data presentation. Median. Determination of point estimate and confidence intervals. KODEKS: an electronic fund for legal and reference documentation. Available at: http://docs.cntd.ru/document/1200035332 (10.07.2020) (in Russian).

${ }^{4}$ Radiation Protection and Safety of Radiation Sources: International Basic Safety Standards, IAEA Safety Standards Series No. General Safety Requirements, Part 3. No GSR-3. Vienna, IAEA Publ., 2014, 477 p.

${ }^{5}$ Radiation Safety Standards (NRB-99/2009). Sanitary-epidemiologic rules and standards SER 2.6.1.2523-09. Moscow, The Federal Center for Hygiene and Epidemiology of Rospotrebnadzor Publ., 2009, 100 p. (in Russian).

${ }^{6}$ MR 2.6.1.0063-12. Control over radiation doses received by population living in a zone close to a radiation object, in a situation when it is functioning properly or when there is radiation emergency. KODEKS: an electronic fund for legal and reference documentation. Available at: http://docs.cntd.ru/document/1200095229 (10.07.2020) (in Russian).

${ }^{7}$ HS 2.1.7.2041-06. Maximum permissible concentrations (MPC) of chemicals in soil. KODEKS: an electronic fund for legal and reference documentation. Available at: http://docs.cntd.ru/document/901966754 (10.07. 2020) (in Russian).

${ }^{8}$ HS 2.1.7.2511-09. Tentative permissible concentrations (TPC) of chemicals in soil. KODEKS: an electronic fund for legal and reference documentation. Available at: http://docs.cntd.ru/document/901966754 (10.07.2020) (in Russian).

${ }^{9}$ MU 2.1.7.730-99. Hygienic assessment of soil quality in settlements. KODEKS: an electronic fund for legal and reference documentation. Available at: http://docs.cntd.ru/document/1200003852 (10.07.2020) (in Russian).
} 
tion in examined soil $\left(\mathrm{C}_{\mathrm{i}}\right)$ and regional background values $(\mathrm{mg} / \mathrm{kg})\left(\mathrm{C}_{\mathrm{fi}}\right)$ :

$$
K_{c}=C_{i} / C_{f i}
$$

The cumulative pollution indexis determined as a sum of concentration factors were determined for all chemical contaminants.

$$
Z_{c}=\Sigma\left(K_{c i}+\ldots+K_{c n}\right)-(n-1)
$$

$\mathrm{n}$ is a number of examined metals;

$K_{c i}$ is a concentration factor of the $i$-th component.

Chemical contamination of drinking water was evaluated according to the Requirements 2.1.4.1074-0 $1^{10}$, and Hygienic Standards GN 2.1.5.1315-03 ${ }^{11}$.

Health risk caused by radiation exposure was calculated using a linear risk coefficient for malignant neoplasms for the overall population $\left(5.5 \cdot 10^{-2}\right)$ according to NRB-99/2009. According to the guidelines (Roshydromet R 52.18.787-2013 ${ }^{12}$ ) on the specific content of artificial radionuclides in soil and drinking water, the public risk was evaluated taking into account the basic exposure pathways.

The calculation of public health risks caused by chemical pollutants (heavy metals) was performed in accordance with the guidelines $\mathrm{R} 2 \cdot 1 \cdot 10.1920-04^{13}$. The individual carcinogenic risk was calculated under the permanent residence scenario. The factors of exposure which provide additional individual carcinogenic risk via the dermal, inhalation and ingestion routes of intake were taken into consideration.

Results and discussion. Site characterization. According to the ecological reports
(2017-2019), the NWC «SevRAO» Gremikha does not discharge radionuclides in the environment at the current stage of decommissioning.

At the industrial site there are local areas under surface and depth soil contamination with artificial radionuclides. Gamma dose rate varies within the range of $0.05 \div 150 \mu \mathrm{Sv} /$ hour (median is $0.44 \mu \mathrm{Sv} /$ hour). The main artificial radionuclides detected in the environment (soil, algae, and bottom sediment) are ${ }^{137} \mathrm{Cs}$ and ${ }^{90} \mathrm{Sr}$. There are also trace concentrations of ${ }^{154} \mathrm{Eu}$ (soil) and ${ }^{3} \mathrm{H}$ (subsoil waters). Ground water is contaminated with ${ }^{90} \mathrm{Sr}$ and ${ }^{3} \mathrm{H}$ radionuclides along with heavy metals in concentrations exceeding MPC. Subsoil- and ground water are polluted predominantly with $\mathrm{Cd}$ and $\mathrm{Tl}$, and $\mathrm{Cd}, \mathrm{Ni}, \mathrm{Al}, \mathrm{Mn}$, and $\mathrm{Zn}$ respectively. Chemical contamination of soil is heterogeneous and represented by the wide spectrum of metals, including $\mathrm{Pb}, \mathrm{Ni}, \mathrm{Cu}, \mathrm{Zn}, \mathrm{V}$, $\mathrm{Cd}$, and As [19].

Therefore, the paper focuses on the analysis of soils and drinking water in the residential area in the vicinity of the nuclear legacy site.

A closed settlement, called Ostrovnoy, is located in the supervision area of the industrial site. The settlement includes two districts, Ostrovnoy and Gremikha, located 1-2 km away from the examined site. As of 2019, the population is 1,842 people [20]. They live in multistorey panel and brick houses equipped with centralized water supply. Water supply for drinking and household needs is carried out from the surface lake (Zmei lake) located $4 \mathrm{~km}$ away from the residential area. The terrain in the examined area is highly irregular; there are rocks, multiple lakes, and moors. Due to harsh

\footnotetext{
${ }^{10}$ SER 2.1.4.1074-01. Drinking water. Hygienic requirements to quality of water taken from centralized drinking water supply system. Quality control. Hygienic requirements to providing safety of hot water supply systems. Hygienic assessment of soil quality in settlements. KODEKS: an electronic fund for legal and reference documentation. Available at: http://docs.cntd.ru/document/901798042 (10.07.2020) (in Russian).

${ }^{11}$ GN 2.1.5.1315-03. Maximum permissible concentrations (MPC) of chemicals in water taken from water objects used for drinking and communal water supply. KODEKS: an electronic fund for legal and reference documentation. Available at: http://docs.cntd.ru/document/901862249 (10.07.2020) (in Russian).

${ }^{12} \mathrm{R} 52.18 .787-2013$. The procedure for assessing radiation risks basing of data obtained via radiation situation monitoring. Obninsk, «VNIIGMI-MCD» Publ., 2014, 116 p. (in Russian).

${ }^{13} \mathrm{R} 2.1 .10 .1920-04$. Guide on assessing health risks under exposure to chemicals that pollute the environment. KODEKS: an electronic fund for legal and reference documentation. Available at: http://docs.cntd.ru/document/1200037399 (10.07.2020) (in Russian).
} 
Table 1

Gamma dose rate in the residential and background area

\begin{tabular}{|l|c|c|c|c|}
\hline \multirow{2}{*}{ Territory } & \multirow{2}{*}{$\begin{array}{c}\text { Number } \\
\text { of measurements }\end{array}$} & \multicolumn{3}{|c|}{ Gamma dose rate, $\mu$ Sv/hour } \\
\cline { 3 - 5 } & 131 & Minimum & Maximum & Median \\
\hline Background area & 0.06 & 0.20 & $0.11(0.07-0.15)$ \\
\hline Ostrovnoy district & 6,538 & 0.06 & 0.21 & $0.07(0.05-0.10)$ \\
\hline Gremikha district & 3,224 & 0.05 & 0.16 & $0.07(0.05-0.10)$ \\
\hline
\end{tabular}

Table 2 exceed permissible activity levels estab-

Specific activity of artificial radionuclides in ambient air in Murmansk region in $2019^{16}$

\begin{tabular}{|l|c|c|c|}
\hline \multirow{2}{*}{ Radionuclides } & \multicolumn{3}{|c|}{ Specific activity, $\mathrm{Bq} / \mathrm{m}^{3}$} \\
\cline { 2 - 4 } & Average & Maximum & $\begin{array}{c}\text { Permissible } \\
\text { activity }\end{array}$ \\
\hline${ }^{137} \mathrm{Cs}$ & $7.8 \cdot 10^{-6}$ & $18.8 \cdot 10^{-6}$ & 27 \\
\hline${ }^{90} \mathrm{Sr}$ & $6.3 \cdot 10^{-6}$ & $9.9 \cdot 10^{-6}$ & 2.7 \\
\hline
\end{tabular}

climate and poor soils, basic flora contains only lichen, shrubby birches, and shrubs. Natural and climatic conditions in this area do not allow engaging in agriculture or animal breeding. All the necessary food products and fuel are delivered by sea or by helicopters. People only consume delivered food.

Radiation situation in the supervision area. Gamma dose rate. Gamma dose rate measured in Gremikha and Ostrovnoy districts corresponds to the regional background level (Table 1) typical for the natural background radiation existing in Murmansk region $^{14}(0.06-0.23 \mu \mathrm{Sv} /$ hour $)$.

Artificial radionuclides in environmental media. The dominant artificial radionuclides in the environment are ${ }^{137} \mathrm{Cs}$ and ${ }^{90} \mathrm{Sr}$. According to the data provided by the operator of the site ${ }^{15}$ the ambient air pollution with artificial radionuclides does not lished in NRB-99/2009. It is also confirmed by the data in the Radiation-hygienic profile issued for Murmansk region territory in 2019 (Table 2).

The specific activity of ${ }^{137} \mathrm{Cs}$ and ${ }^{90} \mathrm{Sr}$ in soil corresponds to the regional background values in the residential area (Table 3).Contamination of soil samples with artificial radionuclides taken in the vicinity to the nuclear legacy site corresponds to the requirements established for unlimited use of solid materials $\mathrm{A}_{\mathrm{UU}}$ according to OSPORB-99/2010 ${ }^{17}$.

The water samples of Zmei lake correspond to the requirements established for drinking water quality for the artificial radionuclides. The specific activity of ${ }^{137} \mathrm{Cs}$ and ${ }^{90} \mathrm{Sr}$ is three orders of magnitude lower than the intervention limit regulated by NRB99/2009 (Table 3).

Public doses. According to the project documentation expected AAED for population due to actual emissions should be $16.34 \mu \mathrm{Sv}$ in the normal operation mode. It is significantly lower than the established dose limit of $100 \mu \mathrm{Sv}^{18}$. Ground-level concentrations of contaminants outside the health protection zone were estimated by the qualitative and quantitative composition of emissions into the

\footnotetext{
${ }^{14}$ Radiation situation in Russia and neighboring states in 2018. Annual edition. Obninsk, 2019, 324 p. (in Russian).

${ }^{15}$ There port on ecological safety issued in 2018 by the North-western Center for Radioactive Wastes Management - a branch of the «RosRAO» Federal enterprise responsible for Radioactive Wastes Management, 2018, 32 p. (in Russian).

${ }^{16}$ The radiation-hygienic profile issued for Murmansk region in 2019, 2019, 11 p. (in Russian).

${ }^{17}$ SR 2.6.1.2612-10. Basic sanitary rules for radiation safety provision (OSPORB-99/2010). KODEKS: an electronic fund for legal and reference documentation. Available at: http://docs.cntd.ru/document/902214068 (10.07. 2020) (in Russian).

${ }^{18}$ The project for substantiating boundaries of a sanitary protection zone for the Gremikha division of the North-western Center for Radioactive Wastes Management, 2017, 143 p. (in Russian).
} 
Table 3

The specific activity of artificial radionuclides in soils and water in the lake located nearby Gremikha district

\begin{tabular}{|c|c|c|c|c|c|c|}
\hline \multirow{3}{*}{ Area } & \multicolumn{6}{|c|}{ Specific activity, $\mathrm{Bq} / \mathrm{kg}$} \\
\hline & \multicolumn{3}{|c|}{${ }^{137} \mathrm{Cs}$} & \multicolumn{3}{|c|}{${ }^{90} \mathrm{Sr}$} \\
\hline & Number of mes & Maximum & Median & Number of mes. & Maximum & Median \\
\hline Soil & \multicolumn{3}{|c|}{$A_{U U}=100$} & \multicolumn{3}{|c|}{$\mathrm{A}_{\mathrm{UU}}=1,000$} \\
\hline Background & 4 & 16 & $8(4-12)$ & 4 & 10 & $0.2(0.2-0.5)$ \\
\hline Ostrovnoy dist. & 8 & 29 & $9(1-13)$ & 5 & 1 & $0.4(0.2-0.9)$ \\
\hline Gremikha dist. & 13 & 31 & $11(1-25)$ & 5 & 0.5 & $0.3(0.2-0.6)$ \\
\hline Water & \multicolumn{3}{|c|}{ Interventional level- 11} & \multicolumn{3}{|c|}{ Interventional level- 4.9} \\
\hline Zmei lake & 2 & 0.003 & 0.003 & 2 & $<0.001$ & $<0.001$ \\
\hline
\end{tabular}

ambient air. They correspond to hygienic requirements SER2.1.6.1032-01 ${ }^{19}$. Therefore, the main exposure pathways are external exposure and internal exposure due to drinking water consumption.

According to TL-dosimeters, external exposure AAED does not exceed $1.63 \mathrm{mSv}$ (Table 4) with its median value by $0.98 \mathrm{mSv}$. External exposure dose inside houses corresponds to its outdoor values.

Considering standard time spent by the population indoors $(6,600$ hours) and outdoors (2,200 hours), the median AAED value for external exposure was $0.85 \mathrm{mSv}$, varying from 0.40 to $1.58 \mathrm{mSv}$.

External exposure to AAED from artificial sources is $10 \mu \mathrm{Sv}$ excluding regional background radiation (natural sources and artificial background radiation from global fallout).
The contribution of artificial radionuclides with drinking water consumption to internal exposure is $0.02 \mu \mathrm{Sv}$.

Total AAED of external and internal exposure from artificial sources is $10 \mu \mathrm{Sv}$ for the population and does not exceed dose limits established by radiation safety standards NRB-99/2009.

Heavy metal contamination of soil and drinking water in the residential area. We've examined the heavy metals in soil samples taken in Ostrovnoy and Gremikha districts and in drinking water samples taken from Zmei lake for elements from all chemical hazard categories.

It was found that the concentrations of metals from the $1^{\text {st }}$ hazard category $(\mathrm{Pb}, \mathrm{As}, \mathrm{Cd}$, and $\mathrm{Zn})$ and he $2^{\text {nd }}$ hazard category $(\mathrm{Ni}, \mathrm{Cu}$, and $\mathrm{Cr}$ ) in soil samples exceed the background values in

Table 4

External exposure AAED near Gremikha district

\begin{tabular}{|l|c|c|c|c|}
\hline \multirow{2}{*}{\multicolumn{1}{|c|}{ Territory }} & \multirow{2}{*}{$\begin{array}{c}\text { Number } \\
\text { of measurements }\end{array}$} & Minimum & Maximum & Median \\
\cline { 3 - 5 } & & & & \\
\hline Background area (Zmei lake) & & 0.40 & 1.40 & $0.97(0.40-1.38)$ \\
\hline - outdoors & 6 & & & $0.98(0.40-1.56)$ \\
\hline Ostrovnoy closed settlement: & & 0.40 & 1.63 & $0.80(0.40-1.30)$ \\
\hline - outdoors & 16 & 0.40 & 1.56 & \multicolumn{2}{c|}{ External exposure AAED, mSv } \\
\hline - inside houses & 6 & & & \\
\hline
\end{tabular}

${ }^{19}$ SER 2.1.6.1032-01. Hygienicrequirementstoprovidingproperambientairqualityinsettlement. KODEKS: an electronic fund for legal and reference documentation. Available at: http://docs.cntd.ru/document/901787814 (10.07. 2020) (in Russian). 
Table 5

The heavy metals in soil in the examined residential area and regional background

\begin{tabular}{|c|c|c|c|c|c|c|c|}
\hline \multirow{2}{*}{ Element } & \multirow{2}{*}{$\begin{array}{l}\text { Chemical haz- } \\
\text { ard category }\end{array}$} & \multicolumn{3}{|c|}{ Heavy metal, $\mathrm{mg} / \mathrm{kg}$} & \multicolumn{2}{|c|}{ Assessment criteria, $\mathrm{mg} / \mathrm{kg}$} & \multirow{2}{*}{$\mathrm{K}_{\mathrm{c}}$} \\
\hline & & Minimum & Maximum & Median & Regional background & MPC/TPC & \\
\hline $\mathrm{Pb}$ & 1 & 35 & 210 & $120(40-190)$ & 18 & 32 & 6 \\
\hline $\mathrm{Cd}$ & 1 & 0.09 & 0.90 & $0.22(0.09-0.63)$ & 0.06 & 0.5 & 3 \\
\hline As & 1 & 0.1 & 1.2 & $0.6(0.1-0.9)$ & 0.3 & 2 & 2 \\
\hline $\mathrm{Zn}$ & 1 & 97 & 980 & $170(101-680)$ & 58 & 110 & 3 \\
\hline $\mathrm{Ni}$ & 2 & 23 & 39 & $34(25-37)$ & 20 & 40 & 2 \\
\hline $\mathrm{Cu}$ & 2 & 15 & 97 & $35(20-78)$ & 12 & 66 & 2 \\
\hline $\mathrm{Cr}$ & 2 & 28 & 120 & $81(31-113)$ & 34 & - & 2 \\
\hline $\mathrm{V}$ & 3 & 47 & 93 & $75(49-83)$ & 48 & 150 & 2 \\
\hline $\mathrm{Mn}$ & 3 & 490 & 610 & $600(502-602)$ & 400 & 1500 & 1 \\
\hline $\mathrm{Ba}$ & 3 & 620 & 790 & $700(630-778)$ & 720 & - & 1 \\
\hline $\mathrm{Sr}$ & 3 & 260 & 300 & $280(265-290)$ & 300 & - & 1 \\
\hline $\mathrm{Zc}$ & & 2 & 28 & $9(2-17)$ & - & - & - \\
\hline
\end{tabular}

soils of this region (Table 5). According to health physics assessment, the $\mathrm{Pb}$ and $\mathrm{Zn}$ concentrations in soils reached up to 7 MPC, 9 TPC, respectively. The soil in the most of the examined areas have a «permissible» contamination level by calculated $\mathrm{Zc}$ index $(\mathrm{Zc}<16)$. The maximum value of $Z c$ is 28 , which characterizes soil contamination as «moderately hazardous». It caused by increased soil concentrations of $\mathrm{Pb}$, $\mathrm{Cd}$, and Zn (Table 5).

Water from the lake contained the following heavy metals in significant concentrations: $\mathrm{Al}(0.011 \pm 0.004 \mathrm{mg} / \mathrm{L}), \mathrm{Fe}(0.03 \pm 0.01 \mathrm{mg} / \mathrm{L})$, and $\mathrm{Mn}(1.0 \pm 0.3 \mathrm{mg} / \mathrm{L})$ without exceeding MPC. We didn't either detect any metals of the $1^{\text {st }}$ chemical hazard category in significant concentrations. Water from the lake corresponds to requirements established for drinking water quality by heavy metals.

Comprehensive analysis of carcinogenic risks for population. The experimental studies on the environmental pollution in the area close to the studied nuclear legacy site formed the basis for carcinogenic risk assessment. Risk calculations based on data from field studies have some uncertainties related to spatio-temporal unevenness of contaminant distribution in the environment, the characteristics of individual exposure, and the time frame of experimental studies. In this work, an assessment of the public health risks during the active phase of SNF and RW management was carried out. The radiation and chemical risks related to environmental contamination with heavy metals were determined according to a conservative scenario for a hypothetical person exposed to radioactive and chemical pollutants during the average life span (70 years). To avoid hazard underestimation, we took the upper limits of the median confidence interval to calculate tentative risks levels at $\mathrm{P}=0.95$ taking into account extended uncertainty of radiation parameters and heavy metal measurements.

We calculated tentative radiation risk levels taking into account exposure to artificial radionuclides in soils and drinking water. According to the requirements R52.18.787-2013 (Table 6) the external exposure risk was found to be an order of magnitude higher than the internal exposure risk for population living in the examined area. The level of the total radiation risk, taking into account the uncertainty, is $5 \cdot 10^{-7}$, which corresponds to the level of «negligible» risk (lower than $1 \cdot 10^{-6}$ ). The risk estimated by the total AAED from all artificial sources also can be considered as «negligible». 
Table 6

The individual radiation risk for people living near the Gremikha district

\begin{tabular}{|c|c|c|c|c|}
\hline \multirow{3}{*}{ Parameter } & \multirow{3}{*}{$\begin{array}{r}\text { Specific } \\
\text { activity, } \\
\mathrm{Bq} / \mathrm{kg}(\mathrm{L})\end{array}$} & \multicolumn{3}{|c|}{ Individual radiation risk } \\
\hline & & \multicolumn{2}{|c|}{ Exposure } & \multirow{2}{*}{ Total } \\
\hline & & internal & external & \\
\hline \multicolumn{2}{|l|}{ Soil } & $3 \cdot 10^{-9}$ & $5 \cdot 10^{-7}$ & $5 \cdot 10^{-7}$ \\
\hline${ }^{137} \mathrm{Cs}$ & 25 & $8 \cdot 10^{-10}$ & $5 \cdot 10^{-7}$ & $5 \cdot 10^{-7}$ \\
\hline${ }^{90} \mathrm{Sr}$ & 9 & $2 \cdot 10^{-9}$ & $1 \cdot 10^{-9}$ & $3 \cdot 10^{-9}$ \\
\hline \multicolumn{2}{|l|}{ Water } & $1 \cdot 10^{-8}$ & - & $1 \cdot 10^{-8}$ \\
\hline${ }^{137} \mathrm{Cs}$ & 0,003 & $1 \cdot 10^{-9}$ & - & $1 \cdot 10^{-9}$ \\
\hline${ }^{90} \mathrm{Sr}$ & 0,001 & $9 \cdot 10^{-9}$ & - & $9 \cdot 10^{-9}$ \\
\hline \multicolumn{2}{|l|}{ Total risk } & $1 \cdot 10^{-8}$ & $5 \cdot 10^{-7}$ & $5 \cdot 10^{-7}$ \\
\hline
\end{tabular}

Note : *means it is the upper limit of median confidence interval at $P=0.95$ allowing for extended measurements uncertainty.

Table 7

Individual carcinogenic risks caused by chemical pollution of the environment

\begin{tabular}{|c|c|c|c|c|c|}
\hline \multirow{2}{*}{ Parameter } & \multirow{2}{*}{$\begin{array}{c}\text { Concen- } \\
\text { tration, } \\
\mathrm{mg} / \mathrm{kg}^{*}\end{array}$} & \multicolumn{3}{|c|}{ Individual carcinogenic risks } \\
\cline { 3 - 5 } & ingestion & inhalation & dermal & \\
\hline \multicolumn{2}{|c|}{ Soil } & $9 \cdot 10^{-8}$ & $2 \cdot 10^{-8}$ & $5 \cdot 10^{-8}$ & $2 \cdot 10^{-7}$ \\
\hline $\mathrm{Pb}$ & 190 & $4 \cdot 10^{-8}$ & $6 \cdot 10^{-9}$ & $2 \cdot 10^{-8}$ & $7 \cdot 10^{-8}$ \\
\hline $\mathrm{As}$ & 0.9 & $3 \cdot 10^{-8}$ & $8 \cdot 10^{-9}$ & $6 \cdot 10^{-9}$ & $4 \cdot 10^{-8}$ \\
\hline $\mathrm{Cd}$ & 0.6 & $5 \cdot 10^{-9}$ & $3 \cdot 10^{-9}$ & $2 \cdot 10^{-8}$ & $3 \cdot 10^{-8}$ \\
\hline $\mathrm{Cr}$ & 113 & $1 \cdot 10^{-6}$ & $4 \cdot 10^{-7}$ & $5 \cdot 10^{-6}$ & $6 \cdot 10^{-6}$ \\
\hline
\end{tabular}

N o t e : * means the upper limit of median confidence interval at $P=0.95$, allowing for extended measurements uncertainty.

We also assessed the tentative risks of carcinogenic effects caused by exposure to heavy metals found in soils in the residential area in concentrations exceeding regional background levels (Table 7). Since we did not detect any carcinogenic potential for $\mathrm{Zn}, \mathrm{Cu}$, and $\mathrm{V}$, the assessment was accomplished for $\mathrm{Pb}, \mathrm{As}, \mathrm{Cd}$ and $\mathrm{Cr}$.
The calculated levels of carcinogenic risks taking into account all intake ways (ingestion, inhalation, and dermal) did not exceed the minimum range of carcinogenic risk (lower than $10^{-6}$ ) and corresponded to the «negligible» acceptance criterion.

Comparing the risks caused by the studied contaminants, we took into account general linear dependence concept for assessing the carcinogenic risks to low exposure doses and low concentrations of carcinogenic chemicals. Our comparison indicates no prevailing contributions made by radiation and chemical pollutants into carcinogenic risks [10].

Conclusions. Health physics situation in the residential area located near the Navy's former shore technical base (Gremikha peninsula) is characterized by background concentrations of artificial radionuclides ${ }^{137} \mathrm{Cs}$ and ${ }^{90} \mathrm{Sr}$ in environmental media. However, heavy metal soil contamination in the residential area is characterized by chemicals concentrations exceeding regional background levels. Comprehensive assessment of carcinogenic health risks to the public caused by exposure to radiation and chemical factors showed comparable results. Risks levels did not exceed $10^{-6}$ and were negligible.

The obtained results show that current industrial activities at the nuclear legacy site NWC «SevRAO» Gremikha during site decommissioning do not create additional risks of exposure to radionuclides and heavy metals for the population and the environment.

Funding. The research was not granted any sponsor support.

Conflict of interests. The authors declare there is no any conflict of interests.

\section{References}

1. Linge I.I., Vorob'eva L.M., Shashina T.A. The structure of environmental risk factors to the population's health in the Kolsky north. Gigiena i sanitariya, 2009, no. 5, pp. 51-54 (in Russian).

2. Smith G.M., Smith K.L., Kowe R., Pérez-Sánchez D., Molinero J. Recent developments in assessment of long-term radionuclide behavior in the geosphere-biosphere subsystem. Journal of Environmental Radioactivity, 2012, vol. 131, pp. 89-109. DOI: 10.1016/j.jenvrad.2013.10.018

3. Sneve M.K., Popic J.M., Siegien-Iwaniuk K. Regulatory Supervision of Legacy Sites: The Process from Recognition to Resolution. Report of an international workshop. Lillehammer, 2017, $115 \mathrm{p}$. 
4. Kotenko K.V., Shandala N.K. Problems of nuclear heritage regulation (review). Saratovskii nauchno-meditsinskii zhurnal, 2013, vol. 9, no. 4, pp. 811-815 (in Russian).

5. Panov A.V., Sanzharova N.I., Perevolotskii A.N., Perevolotskaya T.V., Naumov V.S. Analysis of the current national regulatory system EOF radiation safety of public and radiation protection of environment nearby facilities and sites outside the facilities contaminated with artificial and natural radionuclides due to their past operation. Radiatsiya i risk, 2017, vol. 26, no. 2, pp. 107-121 (in Russian).

6. Blinova L.D., Dushin V.N. Methodological approaches to environmental risk assessment under nu-clear facilities normal operation, comparative risk assessment. Trudy radievogo instituta im. V.G. Khlopina, 2003, vol. 10, pp. 92-105 (in Russian).

7. Arutyunyan R.V., Grachev V.A. Risk-oriented approach to analysis of safety living in the vicinity of atomic energy facilities. Review. Radiatsiya i risk, 2018, vol. 27, no. 2, pp. 117-140 (in Russian).

8. Radioekologicheskaya obstanovka $\mathrm{v}$ regionakh raspolozheniya predpriyatii Rosatoma [Radio-ecological situation in regions where Rosatom enterprises are located]. In: I.I. Linge, I.I. Krysheva eds. Moscow, «SAMpoligrafist» Publ., 2015, 296 p. (in Russian).

9. Rakhmanin Yu.A., Ivanov S.I., Novikov S.M., Revazova Yu.A., Rusakov N.V. Topical problems of the comprehensive hygienic characterization of urban environmental factors and their influence on the population's health. Gigiena i sanitariya, 2007, no. 5, pp. 5-8 (in Russian).

10. Biblin A.M., Zykova I.A., Koroleva T.M., Nikolaevich M.S. Methodological approaches to assessments of health risks in hygienic research. Radiatsionnaya gigiena, 2013, vol. 6, no. 2, pp. 32-38 (in Russian).

11. Panchenko S.V., Arakelyan A.A., Vedernikova M.V., Potsyapun N.P., Kargin O.A., Sikora O.N., Stepanova U.G. Comparative assessment of radiation and chemical risks in the city of Angarsk. Radiatsiya i risk, 2017, vol. 26, no. 2, pp. 83-96 (in Russian).

12. Novikov S.M., Shashina T.A., Dodina N.S., Kislitsin V.A., Skovronskaya S.A., Matsyuk A.V., Panchenko S.V., Arakelyan A.A. The experience of empirical research on comparative assessment of radiation and chemical health risks due to exposure to environmental factors. Gigiena i sanitariya, 2019, vol. 98, no. 12, pp. 1425-1431 (in Russian).

13. Belyaev E.N., Fokin M.V., Novikov S.M., Prusakov V.M., Shashina T.A., Shayakhmetov S.F. Actual problems of improving the assessment of health risk for assurance of the sanitary and epidemiological well-being. Gigiena i sanitariya, 2013, vol. 92, no. 5, pp. 53-55 (in Russian).

14. Romanovich I.K. Termination of the nuclear and radiation legacy of Russia: scientific basis for the radiation-hygienic regulation. Radiatsionnaya gigiena, 2019, vol. 12, no. 3, pp. 114-119 (in Russian).

15. Muratov O.E. Yadernoe nasledie na Severo-Zapade Rossii. Problemy i resheniya [Nuclear legacy in north-western Russia. Problems and solutions]. Atomnaya strategiya, 2019, no. 147, pp. 7-11 (in Russian).

16. Shandala N.K., Kiselev S.M., Titov A.V. Scientific and practical experience of supervisory activities in the field of the public and environmental protection at the Russian nuclear legacy sites. Radiatsionnaya gigiena, 2019, vol. 12, no. 2, pp. 83-96 (in Russian).

17. Kiselev S.M., Akhromeev S.V., Geras'kin S.A., Udalova A.A., Starinskii V.G., Shlygin V.V., Gimadova T.I., Shandala N.K. Assessment of natural environment at nuclear legacy sites are located in far eastern region of Russia. Voprosy radiatsionnoi bezopasnosti, 2017, vol. 88, no. 4, pp. 27-42 (in Russian).

18. Publikatsiya 103 Mezhdunarodnoi Komissii po radiatsionnoi zashchite (MKRZ) [Publication 103 by the International Commission on Radiological Protection]. In: M.F. Kiselev, N.K. Shandala eds. Moscow, OOO PKF «Alana» Publ., 2009, 344 p. (in Russian).

19. Kiselev S.M., Shlygin V.V., Akhromeev S.V., Lashchenova T.N., Starinskaya R., Gimadova T.I., Zozul Ju., Shandala N.K. Regulatory supervision during decommissioning \& dismantling of nuclear submarines in the Russian Northwest. Seventh International Conference on Radiation in Various Fields of Research. Book of Abstracts, 2019, pp. 342. 
20. Ofitsial'nyi sait Pravitel'stva Murmanskoi oblasti [Murmansk regional government - the official web-site]. Pravitel'stvo Murmanskoi oblasti. Available at: https://gov-murman.ru/ (10.07.2020) (in Russian).

Kiselev S.M., Shandala N.K., Lashchenova T.N., Zozul Yu.N., Shlygin V.V., Gimadova T.I., Malakhova A.N. Health risk analysis as per radiation and chemical factors in a zone influenced by a nuclear legacy object. Health Risk Analysis, 2021, no. 1, pp. 38-47. DOI: 10.21668/health.risk/2021.1.04.eng

Received: 20.09.2020

Accepted: 07.02.2021

Published: 30.03 .2021 